\title{
APSA Inaugurates the Robert A. Dahl Award
}

\section{ABOUT THE AWARD}

The Robert A. Dahl Award is awarded annually to an untenured scholar who has produced scholarship of the highest quality on the subject of democracy. Nonladder faculty members and junior tenure-track faculty at universities and colleges are eligible for the Dahl Award, as are scholars at nonprofit organizations and think tanks, and independent scholars.

Scholarship eligible for the Dahl Award includes books, papers, and articles on the subject of democracy.

The inaugural winner is Lee Drutman, Senior Fellow, New America, for his book The Business of American is Lobbying: How Corporations Became Politicized and Politics
Became More Corporate. Read the full citation in the Gazette in this issue.

\section{ABOUT ROBERT DAHL}

Robert Dahl was a giant in the discipline of political science. He wrote a series of landmark books, including A Preface to Democratic Theory and Who Governs? He served as president of APSA from 1966 through 1967 , and participated in countless committees and activities of the Association throughout his long professional career.

Dahl was also especially interested in supporting younger scholars and new talent in the profession and mentored many doctoral students who have become leaders in political science themselves.

\author{
FOUNDER'S CIRCLE \\ James S. Fishkin \\ Jennifer L. Hochschild \\ Ira Katznelson \\ Catharine MacKinnon \\ Jane Mansbridge \\ David R. Mayhew \\ The Honorable David E. Price \\ Rosemary A. Putnam \\ Philippe C. Schmitter \\ Ian Shapiro \\ Rogers M. Smith \\ Sidney Tarrow \\ Jane Thery \\ Elisabeth Wood
}

\section{APSA Renames Helen Dwight Reid Award for Merze Tate}

The Helen Dwight Reid Award is awarded annually for the best dissertation successfully defended during the previous two years in the field of international relations, law, and politics. The Helen Dwight Reid Award was presented for the first time in 1966, and was originally sponsored by the Helen Dwight Reid Educational Foundation.

Minutes from APSA Council meetings at the time give little indication as to why Helen Dwight Reid was selected as the scholar for whom the award was named. However, Helen Dwight Reid was a friend and compatriot of the then-APSA Executive Director, Evron Kirkpatrick, and his wife, Jeanne Kirkpatrick. For many years, the award was funded by the Helen Dwight Reid Foundation, established in tribute to the Kirkpatricks, and for the purpose of "advance[ing] effective American leadership and engagement in ways that promote democratic development, human rights, and a just peace."

\section{ABOUT HELEN DWIGHT REID}

Helen Dwight Reid's primary contribution to scholarship was International Servitudes in Law and Practice, published in 1932 by the University of Chicago Press. Her book delved into the details of peace treaties in international law. She discussed the relationships between nations and how the relationships can be functional and yet respect the sovereignty of individual nations.

\section{RENAMING THE AWARD}

In 2010, the Helen Dwight Reid Foundation ceased to exist, and sponsorship of the award ended. The APSA Council constituted a committee to consider renaming and refunding options for the Helen Dwight Reid Award in 2015. The Committee was chaired by Brett Ashley Leeds, Rice University, and included David Bearce, Erica Chenoweth, Mark Crescenzi, Juliet Johnson, and Laura Sjoberg.
At the 2015 Annual Meeting, the committee developed criteria for a new name of the award, then charged each committee member to brainstorm candidate names. The committee members evaluated the candidates based on the criteria they had established. After discussion, the committee unanimously decided to support a recommendation that the Helen Dwight Reid Award be renamed the Merze Tate Award. Merze Tate's name was originally brought to the attention of the committee by Paula D. McClain, professor of political science and public policy at Duke University. The APSA Council unanimously adopted the committee's recommendation at its spring 2016 meeting in Chicago, Illinois.

\section{ABOUT MERZE TATE}

Merze Tate was the first African American woman to receive a doctoral degree in government (1941, Radcliffe). She published many books and articles, including The Disarmament Illusion: The Movement for a Limitation of Armaments to 1907 (MacMillan and Co. 1942), The United States and Armaments (Harvard University Press 1948), and The United States and the Hawaiian Kingdom: A Political History (Yale University Press 1965). Most of her career was spent as a professor of history at Howard University, although she also traveled as a foreign correspondent and was involved in some policywork. In addition to her scholarly contributions to the discipline, Tate's work has been profiled in PS: Political Science and Politics and White World Order Black Power Politics: The Birth of American International Relations, by Robert Vitalis (Cornell University Press 2015), and is the subject of at least one intellectual biography in progress.

In choosing to name the award after Merze Tate, the committee noted that "her perseverance in the face of significant structural obstacles is inspiring and particularly meaningful for a dissertation award." - 